Jpn. J. Oral Biol., 31 : 248-256, 1989.

\title{
ヒト小睡液腺培養細胞から腺房細胞の樹立
}

\author{
清 信 成 一 \\ 東北大学・菌学部・口腔細菌学講座（主任：熊谷勝男教授） \\ 〔受付：炤和63年12月13日〕
}

\section{Establishment of acinar cells from human salivary gland tissue by transformation of $\mathrm{SV}_{40}$}

\author{
Seiichi Kiyonobu \\ Department of Oral Bacteriology, Tohoku University \\ School of Dentistry 4-1 Seiryo-machi, Sendai 980 \\ (Chief: Prof. K. Kumagai) \\ [Accepted for publication: December 13, 1988]
}

Key words: Human acinar cells/transformation/saliva

\begin{abstract}
A piece of minor salivary gland tissue obtained from the lip of a 16 years old female was minced to about $3 \mathrm{~mm}^{3}$ by fine pincettes and cultured with $10 \%$ FCS containing MEM supplemented with EGF $(10 \mathrm{ng} / \mathrm{ml})$, fungizon $(10 \mathrm{mcg} / \mathrm{ml})$ and kanamycin $(60 \mathrm{mcg} / \mathrm{ml})$ in a $5 \% \mathrm{CO}_{2}$ incubator. Many small bubbles of saliva were found on the surface of the fragments after 3 to 4 days of incubation and outgrowth of cells from the fragments was observed from 7 days of incubaton. Monolayer cells of the outgrowth were trypsinized and passaged with fresh culture medium. At the 8 th passage, monolayer cells were infected with $\mathrm{SV}_{40}$ at moi $100 \mathrm{PFU} / \mathrm{cell}$. After 18 hour-incubation, the suspension of the infected cells was incubated at densities of $10^{4}$ and $10^{3}$ cells/dish within $0.33 \%$ agar containing culture medium. Transformed colonies were picked up from soft agar medium and 3 of the 28 colonies were identified as being acinar cells of the salivary gland, since secretory granules and mucosubstances were specifically proved in the cytoplasm of these cells after 2 to 4 days of incubation. One of the typical clone cells was named HA-16 cells. However, the appearances of the secretory granules and mucins in the cytoplasm of the HA-16 cells depended on the cellular growth cycle, i. e. secretory granules and mucins were not found in the growing cells $\left(\mathrm{G}_{1}-\mathrm{S}-\mathrm{G}_{2}-\mathrm{M}\right.$ phase) but many secretory granules and mucins could be recognized in the non-dividing cells ( $\mathrm{G}_{0}$ phase). These results suggest that a clonal acinar cell line can be established from human minor salivary gland and that this cell line is useful for the investigation of the mechanism of saliva production.
\end{abstract}

\section{緒言}

唾液腺は 終末部の 部位とその大小などによっ て, 耳下腺, 顎下腺, 舌下腺の三大喠液腺と, 口唇 腺, 煩腺, 白歯腺，口蓋腺，舌腺などの小唾液腺に 分けられている。また終末部の分泌細胞の差によ って, 漿液腺, 粘液腺, 混合腺の三種類に分類さ れ，漿液腺には耳下腺とエブネル腺，粘液腺には 口蓋腺, 煩腺, 舌口蓋腺と口唇腺, 混合腺には顎

仙台市星陵町 4-1（广980）
下腺と舌下腺などが含まれる。これ等の唾液分泌 機構に関しては，自律神経支配下にあり副交感神 経刺激により漿液性唾液が分泌され，また交感神 経刺激では粘液性唾液の分泌が促されるとされて いる。この様な漿液性や粘液性の唾液の組成につ いて, Mason and Chisholm ${ }^{1}$ 等の報告があるが， 混合唾液の組成は各唾液腺の活動状態により変わ ってくる。1916年, Lashleyにより考案されたカ ニューレを耳下腺導管開口部に 挿入する Clarlson-Crittenden 法や1953年, Curby により改良 された内環と外環を持つ Curby cup 法が古い唾 
液採取法としてあるが Schneyer ${ }^{2}$ によって開発さ れた顎下腺と舌下腺からの唾液採取器が 報告さ れ，さらに Truelove 等 ${ }^{3}$ により本装置の改良型 も報告されている。しかし，これ等の方法で採 取された唾液の組成を調べても，Shannon and Prigmore" の報告にある様に唾液分泌には日常り ズムがあり，採取する日と時間により唾液組成と 分泌量は変化する。この様に唾液組成は刺激の種 類により唾液分泌速度が異なる事と各唾液腺から の分泌量も変動する事から, 正確な唾液の組成は 把握されていない。また, 舌下腺と小喠液腺から分 泌される唾液の組成については採取する事が困難 である為に十分に研究されていない。

この様な事から，ヒトまたはマウスの唾液腺組 織を培養して細胞レベルで喠液分泌の機構を解析

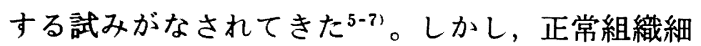
胞は分裂回数が25 55 回の範囲で life span を生 じて死隇する事 ${ }^{8-101}$ と, 唾液腺を構成する種々の 細胞から唾液分泌細胞のみを選択的に 培養しクロ ーン化する事は困難である事 ${ }^{11}$ 等が唾液分泌機構 を細胞レベルで研究するにあたり問題となってい る。

本研究ではヒト（16歳, 女性）の口唇から小喠 液腺組織を摘出し，ピンセットで細分してから， 組織培養し， 8 代継代培養時に腫瘍ウイルスであ る Simian Virus $40\left(\mathrm{SV}_{40}\right)$ を感染させ, トラン スフォームしたコロニーを取り出し, 酸性ムコ多 糖体を細胞質内に産生するクローン 細胞が得られ た。この細胞は樹立細胞として継代可能であり, 小唾液腺の腺房細胞と考えられる事から, 唾液組 成の研究及び 細胞レベルでの唾液産生機構の研究 に有用と考えられたので，この細胞の性状につい て報告する。

\section{材料と方法}

\section{1. 培養材料}

培養材料は 東北大学・歯学部附属病院 - 口腔診 断科に来院した 16歳女性の口唇粘液のう胞患者か らのう胞を摘出した際, 切除した部分から小唾液 腺組織を分離して使用した。組織片はただちに氷 冷した MEM 培地に入れ, 無菌室内でピンセッ トを用いて約 $3 \mathrm{~mm}^{3}$ の大きさに 細分し, 新しい
MEM 培地に小片を移し変える事により脱血し た。

2. 唾液腺組織片の細胞培養

小唾液腺の組織片は $10 \%$ fetal bovine serum (FBS), $10 \mu \mathrm{g} / \mathrm{m} l$ のファンギジン (シグマ社), $10 \mathrm{ng} / \mathrm{ml}$ の epidermal growth factor (EGF ; 日 本ヶミカルリサーチ社) $)^{12}, 100 \mathrm{U} / \mathrm{m} l$ の penicillin 及び $100 \mu \mathrm{g} / \mathrm{ml}$ の streptomycin を加えた MEM 培地を用いて $37^{\circ} \mathrm{C}, 5 \% \mathrm{CO}_{2}$ インキュベータ ーで培養した ${ }^{13)}$ 。

組織片より outgrowth ${ }^{14)} し た$ 細胞はトリプシン $(0.25 \%)$-EDTA $(0.02 \%)$ 処理にて分散し, 初 代継代培養した。2 代から 8 代継代時には, トリ プシンーEDTA 処理時間を短くし, 線維芽系細胞 が培養容器から離脱した時に PBS で洗浄し, 残 った上皮系細胞を再びトリプシンーEDTA 処理 を行い, 出来る限り上皮系細胞を継代する様にし た。 8 代継代時にて約 $80 \%$ は上皮系細胞の形態を 示していた。

3. トランスフォーメイション

マイコプラズマ陰性の CV-1 細胞で増殖した $\mathrm{SV}_{40}$ を実験に供した。 $\mathrm{SV}_{40}$ の感染価は $10^{7.8} \mathrm{PF}$ $\mathrm{U} / \mathrm{m} l$ を示し， 8 代継代培養細胞の 1 細胞あたり $100 \mathrm{PFU}$ の感染価 (multiplicity of infection $100: \mathrm{moi}=100)$ の割合で感染させ，18時間,

$37^{\circ} \mathrm{C}$ で培養した。この感染細胞をトリプシン一 EDTA 処理にて分散した後, $0.33 \%$ 寒天含 ME$\mathrm{M}$ 培地 (10\% FBS, 10ng/ml EGF 加) 中で培 養した。コロニーを形成した細胞をトランスフォ 一ム細胞 ${ }^{151}$ として採取し, 各コロニー毎に継代培 養し，クローン細胞とした。

4. 腺房細胞の同定

トランスフォーム細胞として得られたクローン 細胞について, 分泌顆粒を同定する為に $4{ }^{\circ} \mathrm{C}$ 小 ルマリン 蒸気固定後五重染色 (Alcian Blue, 0.5 \%過ヨウ素酸 Schiff, Haematoxylin, Orange G, ライトGreen）及び PAS 染色を行った。酸性 ムコ多糖体（ムチン）染色としてコロイド鉄染色 法により，細胞内ムチン産生を調べた。また，培 養細胞をグルタールアルデヒド固定後に 金蒸着し 走查型電子顕微鏡（日立 570型）により細胞表面の 分泌物の観察を行った。また，正常ヒト小唾液腺 
組織のパラフィン包埋切片を用いて五重染色によ る分泌顆粒及びコロイド鉄によるムチン染色を行 い，唾液腺組織細胞に見られるムチン陽性である 腺房細胞の染色像とクローニングされた細胞の 染 色像と比較した。

\section{5. 増殖曲線の作成}

クローン細胞のうち腺房細胞と同定されたもの について増殖曲線を作成し，同時に細胞質内の分 泌顆粒及びムチンの関係も調べた。トリプシンー EDTA で細胞分散後, $10^{5}$ cells $/ \mathrm{m} l$ に細胞濃度 を10\% FBS 含 MEM 培地で調整し， $2 \mathrm{ml}$ を組 織培養用 $\operatorname{dish}(35 \mathrm{~mm} \phi)$ に入れて $5 \% \mathrm{CO}_{2}$ イン キュベーターで培養した。経日的に dish を取り 出して, トリプシンーEDTA 処理をして細胞数 を血球計算盤にて測定した。

\section{結果}

1. 腺房細胞のクローニング

小唾液腺の組織片を培養開始してから48時間後 にはプラスチック面に接着した。その後 $3 \sim 4$ 日 目から接着組織片の表面に唾液の分泌上思われる 泡状の分泌物が認められる組織片 (Fig. 1) が観 察された。この水泡状のものは培養開始時には認 められなかった事から，培養状態になってから出 現したものと考えられた。培養 1 週間にて組織片 の周辺部より線維芽系細胞の outgrowth が始ま り，培養日数の 増加 と共に組織片の 周囲からの outgrowth した単層細胞は広がりを示した（Fig． 2)。培養後 4 週間では組織片の塊はプラスチック 面から脱落し outgrowth で形成された単層細 胞のみとなった。この培養細胞をトリプシンー EDTA 処理により, $10^{5} \mathrm{cells} / \mathrm{m} l$ の細胞濃度で 継代培養した。この細胞は 1 週間の培養で単層細 胞を形成し形態的に大部分が線維芽系細胞であっ た。線維芽系細胞は上皮系細胞よりトリプシン感 受性が高い事を利用し, 単層細胞をトリプシンー EDTA 処理後, プラスチック面より離脱した細胞 をPBS で洗浄し, 再びトリプシンーEDTA 処 理をして，出来る限り上皮系細胞を継代する様に 試みた。この方法で 8 代継代した時の単層細胞は $80 \%$ が形態的に上皮系細胞であった。この細胞に $\mathrm{SV}_{40}$ を moi $\mathrm{SV}_{40} 100 \mathrm{PFU} /$ cell の割合で感染さ

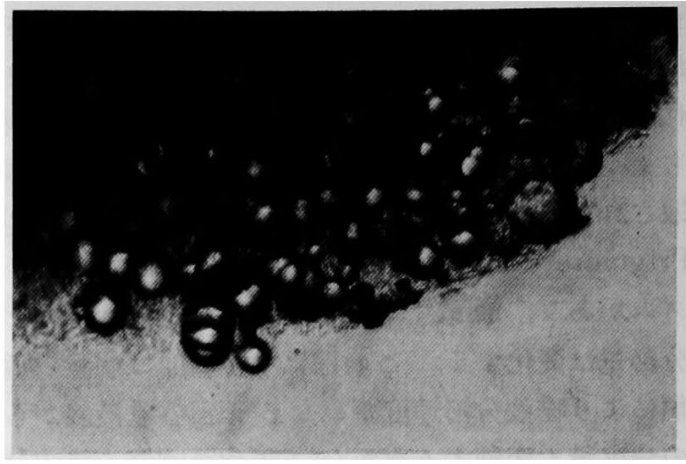

Fig. 1 Small bubbles of saliva shown on the fragments of salivary gland tissue after 3 days of culture. $(\times 100)$

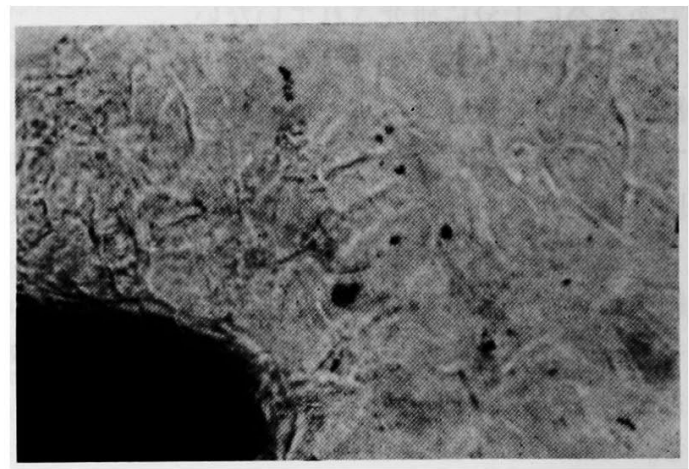

Fig. 2 Outgrowth of cells from the fragments after 14 days of culture. $(\times 200)$

せ, 18 時間後にトリプシンーEDTA処理し, 分散し た細胞を $0.33 \%$ 寒天含 MEM 培地に混合し, $10^{4}$ または $10^{3} \mathrm{cells} / \mathrm{dish}(6 \mathrm{~cm} \phi)$ の 条件で培養し, 10 日毎に0.5ml の MEM 培地を補充した。約 2 週 間培養頃からコロニー形成が認められ，4 週間後 には肉眼的に認められるコロニーまでに成長した (Fig. 3)。また一部の細胞は MEM 培地を用い て $9 \mathrm{~cm}$ 径 dish で培養した。コロニーを形成した トランスフォーム細胞はクローニング・リングを 用いて取り出し，トリプシン一EDTA 処理して 細胞分散を行い, 各コロニー毎に MEM 培地に て継代培養した。最終的に継代可能になった 28 個 のクローン細胞の中で細胞表面から粘液物質を 産 生している 3 個のクローン細胞が見い出された。 この事は培養した小唾液腺の組織片から増殖した 細胞の中で腺房細胞がトランスフォームして，こ れがクローン化された可能性があり, 粘液様物質 の産生が多くて細胞増殖のよいクローンを選び コ 


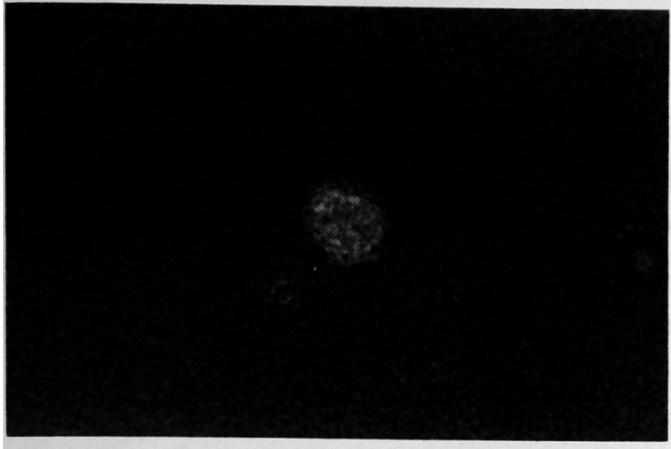

Fig. 3 Colony of transformed cells infected with $\mathrm{SV}_{40}$ from the culture cells of minor salivary gland tissue after 21 days of culture. $(\times 200)$

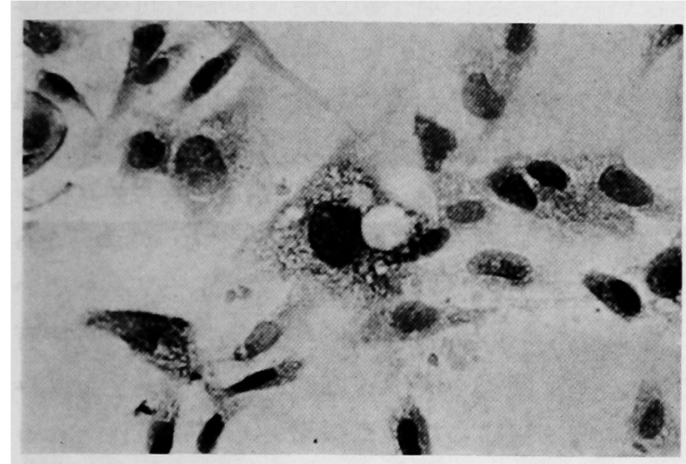

Fig. 4 May-Gruenwald's and Giemsa's stained HA-16 cells after 5 days of culture. $(\times 400)$

ロニーのコード番号から HA-16 細胞と称してこ の細胞の性状について解析を進めた。本実験に用 いた段階での HA-16 細胞は軟寒天培地でコロニ 一形成後, プラスチック・フラスコで 18〜24代継 代培養されたものである。

2. 腺房細胞の同定

HA-16細胞をトリプシン一EDTA で分散後, ス ライドガラス上で 5 日間培養し，メタノール固定 後, ギムザ染色した細胞を Fig. 4 に示した。細胞 質内に特異的に大きな空胞が見られ，他のクロー ン細胞にはこの様な空胞は認められなかった。同 様にスライドガラス上に培養した HA-16 細胞を1 日, 2 日, 3 日と経日的に取り出し, 中性ホルマリ ンで固定後, 分泌顆粒を染色する目的で五重染色 した時, Fig. 5 に示した様に細胞質内に分泌顆粒 が明瞭に染色された。この分泌顆粒は培養後，1 日目の細胞では弱く，3日目の培養細胞は分泌顆

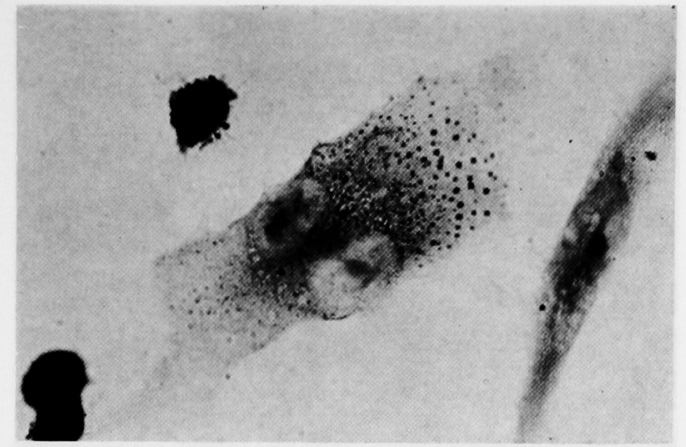

Fig. 5 Haematoxylin-Alcian blue Pass-Masson stained HA-16 cells after 3 days of culture. $(\times 400)$

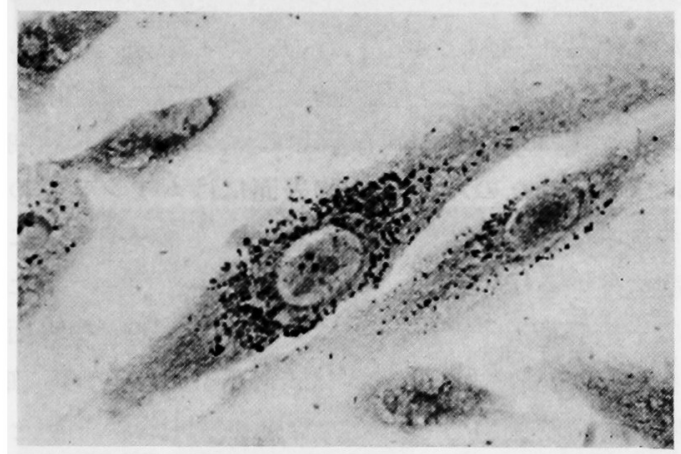

Fig. 6 Colloidal iron stained HA-16 cells after 3 days of culture. $(\times 400)$

粒を保有する細胞の数及び 細胞内に認められる分 泌顆粒の数ともに最高を示した。 5 日目以降の培 養細胞は細胞質内に空泡が多く分泌顆粒の 判別は 困難であった。この HA-16 細胞は分泌顆粒を保 有する事が確認されたが， ギムザ染色で示された 空胞の組成を調べる目的でムチンを特異的に染色 するコロイド鉄染色を試みた。実験試料として培 養 1 日， 2 日， 3 日，5 日及び 7 日の HA-16 細胞 とヒト小㕰液腺組織のパラフィン包埋切片を用い た。Fig. 6 に 3 日培養した HA-16 細胞のコロイ ド鉄染色像を示し，Fig. 7 にパラフィン包埋の小 唾液腺組織切片の同染色像を示した。HA-16 細胞 に示されたムチン顆粒は核周辺から細胞質膜にか けて広く分布しているが，核周辺に密に分布する 傾向が認められ一部ムチンの 細胞外への遊出を思 わせる部分もあった。 また，小唾液腺組織切片で は明らかに腺房細胞のみがムチン陽性であり，他 


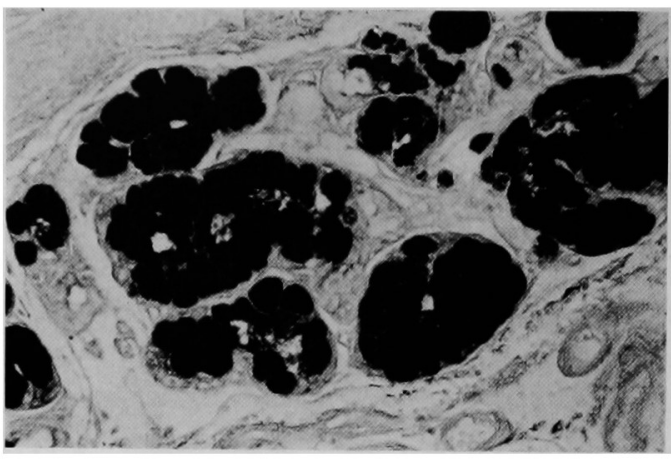

Fig. 7 Colloidal iron stained thin section of human minor salivary gland tissue. $(\times 400)$

の組織細胞にはムチン陽性細胞は認められなかっ た。HA-16 細胞に示されたムチンも培養開始から 1 日目は弱く，その後は培養日数と共に細胞内の ムチン量は増加の傾向を示した。しかし，細胞内 に認められたのみで， 細胞表面にはムチンを認め る事が出来なかった。この事は固定及び染色中に 細胞外のムチンは洗い流された結果と思われたた め, 走查型電子顕微鏡により HA-16 細胞の 表面 を観察した。3日及び 5 日間培養した HA-16 細 胞と非分泌細胞としてヒト胎児肺 (HEL) 細胞を コントロールとして用いた。Fig. 8 a， b , c， d に HA-16 細胞を示し, Fig. 9 に HEL 細胞を 示した。Fig. 8 はいずれもHA-16 細胞表面に分 泌物状の小胞が見られ，a は分泌初期と思われ， b， c の順で細胞表面に分泌物が多くなっている。 また 5 日間培養した HA-16 細胞は d に示した が，細胞表面は分泌物様物質で覆われていた。 Fig. 9 に示した HEL 細胞には分泌物状のものは 細胞表面に何等認められなかった。

HA-16 細胞の増殖曲線 と 細胞質内 の 分泌顆粒 及びムチンの関係を Fig. 10 に示した。トリプシ ン一EDTA で細胞分散後, $10^{5} \mathrm{cells} / \mathrm{m} l$ に細胞濃 度を調整し， $2 \mathrm{~m} l$ を組織培養用 $\operatorname{dish}(35 \mathrm{~mm} \phi)$ で培養した。細胞は培養開始後，1日目で減少を 示し， 2 日目から 5 日目まで増殖を示し， 6 日目 から急速に減少が始まり，10日目では生細胞は認 められなくなった。この事から HA-16 細胞の継 代維持には 3〜 4 日毎に 培養細胞を継代する事が 必要であることが示された。

\section{考察}

唾液の産生に関する研究は古くから行われてい るが，いずれも動物またはヒトを用いた in vivo の実験であり，細胞レベルでの実験は 不可能であ った。電子顕微鏡の発達により, 細胞レベルの観 察は可能になったが，唾液腺組織細胞中での細胞 であり，腺房細胞にはひだ状のインフォールデン グがあって細胞表面積を増やして吸水反応を高め ている事，細胞質内には分泌顆粒がある事，また 唾液を 細胞外に放出する為に多数のマイクロビラ イがある事等の 形態的特徴があげられているにす ぎない。この様に電子顕微鏡では形態的な観察は 出来ても，細胞レベルでの唾液分泌機構の解析は 不可能である。丸茂等の研究 ${ }^{13}$ でヒト小唾液腺組 織片の培養の報告があるが，正常細胞の培養には 細胞自身の持つ life $\operatorname{span}^{8-10)}$ があり，クローン 化して継代細胞株として樹立する事は 不可能であ る。本研究では腫瘍ウイルスである $\mathrm{SV}_{40}$ を用い て細胞をトランスフォームさせ，その中から特有 な唾液分泌機能を有する細胞のクローン化を試み た。唾液腺組織には構築組織として多く含まれる 線維芽系細胞と導管・介在部導管及び 腺房細胞を 構成する上皮系細胞がある。培養開始時には線維 芽系細胞が大部分であった事から，トリプシン感 受性は線維芽系細胞が高い事を利用し，出来る限 り線維芽系細胞を培養細胞から排除するよう努力 した。 $\mathrm{SV}_{40}$ 感染により 軟寒天培地で形成したコ ロニーの内, 28 個のクローン細胞が得られたが, 3 つのクローン細胞が細胞表面に粘液様物質を 産 生し，この 3 つのクローン細胞にのみ五重染色で 分泌顆粒が細胞質内に認められた。この中から細 胞増殖の良いクローン番号 16 である細胞を HA16 細胞として，その性状を代表的線維芽細胞であ る HEL 細胞と比較した。HA-16 細胞には細胞 質内に分泌顆粒が 認められると共にコロイド鉄染 色により細胞質内にムチンが産生されている事が 確認された。他方，HEL 細胞にはいずれも認め られなかった。また，ヒト小唾液腺組織のパラフ イン切片では腺房細胞のみにムチン陽性細胞が認 められた事から，HA-16 細胞はヒト小唾液腺の腺 房細胞がその機能を保持したまま $\mathrm{SV}_{40}$ でトラン 

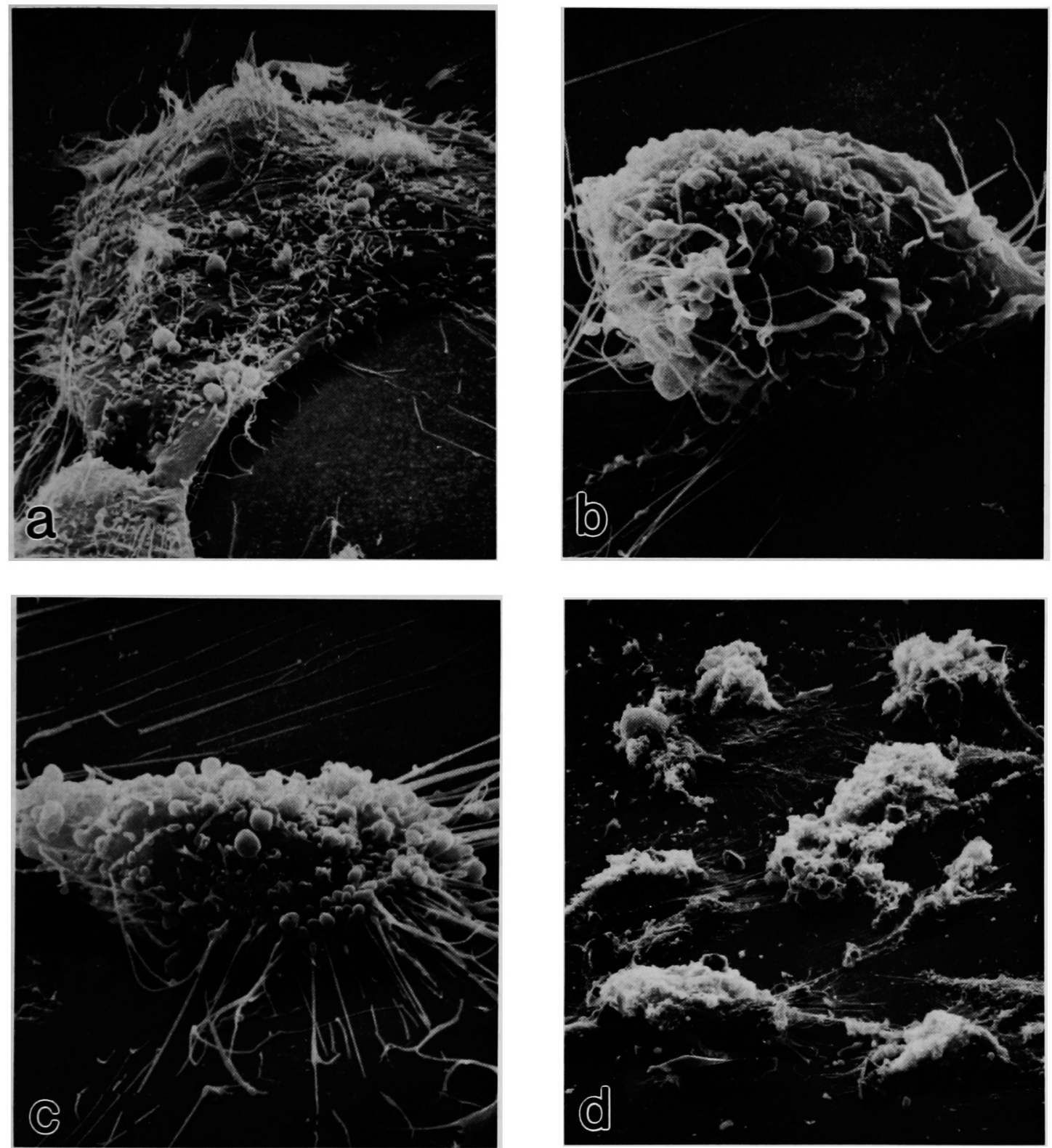

Fig. 8 Observation of the suface of HA-16 cells by electron microscopy after 3 days (abc) and 5 days (d) of culture. (a ; $\times 3500, \mathrm{~b}: \times 5000, \mathrm{c} ; \times 2200, \mathrm{~d} ; \times 700)$

スフォームして，クローン細胞として樹立された と考えられる。HA-16細胞は培養開始から 3 日ま での間に分泌顆粒とムチンを細胞質内に 経日的に 蓄積する事, 5 日培養では走查型電子顕微鏡で認 められた様に細胞表面に多くの分泌物が 排出され ている事, HA-16細胞の細胞増殖曲線で示された 様に培養開始から4 日まで細胞増殖を行い，その
後増殖停止した後で生細胞数が減少する事と考え 合わせると, HA-16細胞は $\mathrm{G}_{1}$ 相 $\rightarrow \mathrm{S}$ 相 $\rightarrow \mathrm{G}_{2}$ 相 $\rightarrow \mathrm{M}$ 相のサイクルで細胞分裂を行い増殖するが, 単層細胞形成が近うき分裂サイクルを停止する $\mathrm{G}_{0}$ 相になると細胞の分泌機能発現が行われ, 分 泌顆粒とムチン合成が活発となり細胞外にムチン を分泌し続ける状態になるものと考えられる。こ 


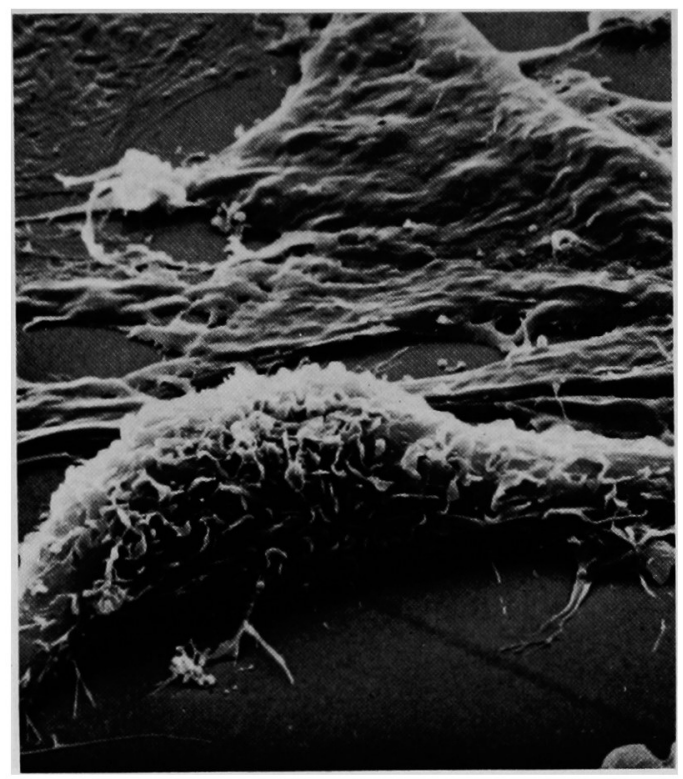

Fig. 9 Observation of the surface of HEL cells by electron microscopy after 3 days of culture. $(\times 3000)$

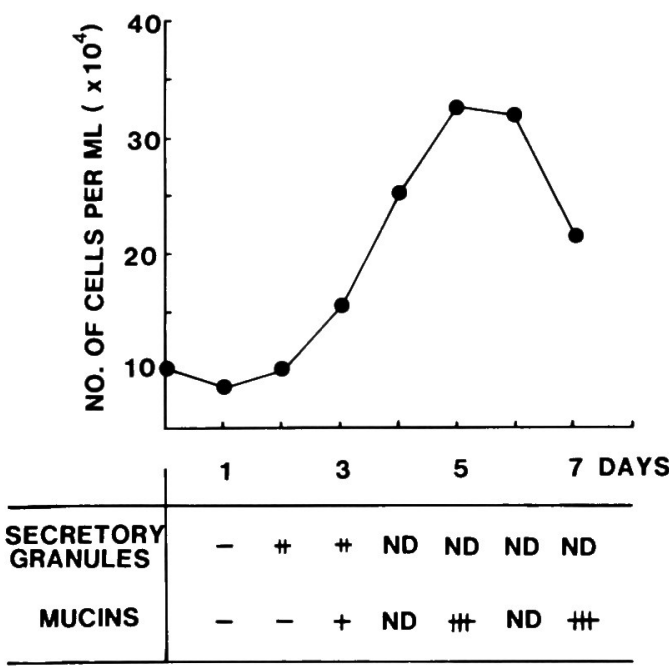

Fig.10 Comaprison of HA-16 cells growth with appearances of secretory granules and mucins in cytoplasm of HA-16 cells.

の事から HA-16 細胞を 継代培養する時は腺房細 胞として機能を発現する前に継代する必要性をも 示している。

唾液の産生に関しては細胞には pinocytosis に よる細胞吸水作用があることや，小胞で合成され る酵素や糖タンパク質はゴルジ装㯰に送られてか
ら分泌顆粒に取り込まれて唾液が作られることが 明らかになっている。この唾液の産生はピロカル ピンで増加し，アトロピンによって抑制される ${ }^{181}$ が，HA-16細胞は $\mathrm{G}_{0}$ 相になってから細胞質内に 分泌顆粒及びムチンが認められる 事はこれ等の薬 剂による抑制ではなく，細胞増殖停止に伴う細胞 機能の発現と考えられる。

唾液中には消化作用物質としてアミラーゼ17,18) があり，また，抗菌作用物質 ${ }^{19 !}$ も含まれており， リゾチーム ${ }^{20,211}$ ，ペルオキシダーゼ22)， IgA 抗 体 ${ }^{23)}$ ，ロイコタキシン2'及びオプソニン25)が研究 されている。しかし，これ等の物質は 3 大唾液腺 及び小唾液腺から分泌された混合唾液によるもの で，どの様な唾液腺でこれ等の物質が産生されて いるか不明である。HA-16細胞から分泌されてい る物質にこれ等の物質のどれが含まれているか解 析していないが，小唾液腺組織の腺房細胞由来で ある HA-16 細胞の分泌物にどの様な物質が含ま れているか興味ある事である。また，唾液腺組織 の抽出物には神経成長促進因子 $(\mathrm{NGF})^{26)}$ や上皮 成長促進因子 $(\mathrm{EGF})^{27}$ が含まれて未分化細胞か ら分化促進する為の組織形成に重要な 因子である が，唾液腺組織細胞でこれ等の物質の生成場所は 不明とされている。一般に線維芽系細胞から colony stimulating factor $(\mathrm{CSF})^{281}$ が産生されてい るが，HA-16細胞の様な分泌機能を有する上皮系 細胞が NGF または EGF 産生に関与しているか 否かを調べる事で，これ等の因子の生成細胞を同 定する上で腺房細胞の関わり合いを追求出来るも のと思われる。

唾液は漿液性唾液と粘液性唾液に分けられ, HA-16 細胞は口唇の小吽液腺からクローニング されたので粘液性唾液を産生する腺房細胞由来と 考えられる。ヒトの小唾液腺組織切片のコロイド 鉄染色によって特異的に腺房細胞に認められたム チン陽性細胞と同じ様に，HA-16細胞にムチンが 認められ分泌機能を保有していることが示され た。唾液成分の組成についてはヒトや動物から採 取された唾液が用いられているが，常に細菌污染 があり唾液成分は細菌により唾液の蛋白分解 ${ }^{291}$ や 糖分解 ${ }^{30)}$ を受けていると報告されている。この事 は正確な 唾液組成を測定する事は困難であること 
を示している。。また, 細胞レベルでの唾液の産生 機構について 解析されていない。HA-16 細胞は $\mathrm{SV}_{40}$ によりトランスフォームされたクローン細 胞であるが，分泌顆粒及びムチンが細胞質内に認 められ，細胞表面には分泌物の蓄積があった事か ら，HA-16細胞は唾液産生及びそれを細胞外に分 泌する機能を保持していると考えられる。以上よ り HA-16 細胞は正常七ト喠液腺組織の腺房細胞 が $\mathrm{SV}_{10}$ によりトランスフォームし, 軟寒天培地 中で 1 個の細胞からコロニーを形成した事は正常 細胞は軟寒天培地中でコロニーを形成し得ない事 から, $\mathrm{SV}_{40}$ によりトランスフォームした細胞と云 える。また,この細胞は継代可能な事から唾液組成 及び 唾液産生機構を細胞レベルで解析する事が可 能になるものと思われる。

\section{結 論}

ヒト口唇の小喠液腺組織片を細分して培養し， 増殖した細胞を 8 代継代培養後， $\mathrm{SV}_{40}$ でトラン
スフォームして28個のコロニーが得られた。これ 等のコロニーを継代培養して，その性状を調べた 所， 3 個のコロニーから由来した細胞の細胞質内 に分泌顆粒とムチンを有する事が認められた。ま た，走査型電子顕微鏡により細胞表面に分泌物と 見られる小胞が認められ，培養 5 日目では細胞全 体を覆うまでになった。ヒト口唇の小唾液腺組織 切片では腺房細胞のみムチン陽性であり，ヒト胎 児肺細胞では 分泌顆粒及びムチンが認められなか った。これ等の事実から $\mathrm{SV}_{40}$ でトランスフォー ムとして得られた細胞は小唾液腺の腺房細胞であ ると結論した。

謝辞：稿を絶えるにあたり,この研究の御指導を賜り ました当教室主任の熊谷勝男教授に謹んで感謝の意を表 します。また実験指導に助言をいただいた清水義信助教 授及び菅野恵美様に感謝いたします。細胞染色に御協力 いただきました口腔診断科の丸茂町子請師及び電子顕微 鏡写真に御協力いただきました第二保存科の笹崎弘已講 師の各位に感謝いたします。

抄録：口唇の小唾液腺組織（16歳・女性）を培養した時，組織片の表面に吽液の分泌が見られ，その後唾 液組織片の周辺から細胞増殖が見られた。この細胞を 8 代継代培羕し， SV 40 を感染させトランスフォーム細 胞を作り，28個のコロニーが得られたが，その内 3 個のコロニーは細胞質内に分泌顆粒とムチンの産生が認 められた。また, ヒト口唇の小喠液腺組織切片では, 腺房細胞のみがムチン陽性であった。この事から分泌顆 粒とムチン陽性を示した細胞は小唾液腺の腺房細胞がトランスフォームした細胞と結論した。この細胞を継 代培垗した時，培養初期の細胞増殖期では分泌顆粒の出現とムチンの産生は細胞質内に弱く認められたが， 単層細胞を形成しつつある細胞では細胞質内と細胞表面にムチンの産生が強く認められた。これ等の事実は 小唾液腺の腺房細胞が唾液分泌機能を保有してトランスフォームし，クローン細胞として樹立された事を示 している。

\section{文献}

1) Mason, D. K. and Chisholm, D. M. : Salivary glands in health and disease. Saunders London, 1975.

2) Schneyer, L. H. : Method for the collection of separate submaxillary and sublingual salivas in man. J. Dent. Res. 34 : 257-261, 1955.

3) Truelove, E. L. Bixler, D. and Merritt, A. D. : Simplified method for collection of pure submandibular saliva in large volumes. J. Dent. Res. 46 : 1400-1403, 1967.

4) Shannon, I. R. and Prigmore, J.R. : Parotid fluid as a medium for the determination of human adrenocorticoid status. Oral Surg. Med. Path. 13 : 878-882, 1962.
5) Shirasuna, K. Sato, M. and Miyazaki, T. : A myoepithelial cell line established from a human pleomorphic adenoma arising in $\mathrm{mi}$ nor salivary gland. Cancer $45: 297-305$, 1980.

6）飯塚桂司：ヒト耳下腺導管細胞のパロチン吸着 現象. 医学のあゆみ $116: 1002-1004,1981$.

7）田隅泰信, 久米川正好: 唾液腺の培養. 組織培 養 $3: 8-20,1977$.

8) Hayflick, L.: The limited in vitro lifetime of human diploid cell stain. Exp. Cell Res. 37 : 614-636, 1965.

9) Hayflick, L. and Moorehead, P. S.: The serial cultivation of human diploid cell strains. Exp. Cell Res. 25 : 585-621, 1961.

10）黒田行昭：培盖細胞の老化. 細胞 $9: 13-21$, 
1977.

11) Oliver, C. : Isolation and maintenance of differentiated exocrine gland acinar cells in vitro. $16: 279-305,1980$.

12) Cohen, S. and Elliot, G. A. : The stimulation of epidermal keratinization by a protein isolated from the submaxillary gland of mouse. J. Invest. Dermatol. $40: 1-5,1963$.

13) Marumo, M. Furuuchi, T. Sanjo, D. Shimizu, Y. and Kumagai, K. : Cell culture of normal human salivary gland. Jpn. J. Oral Biol. 28 : 62-68, 1986.

14) Brown, A. M.: In vitro transformation of submandibular gland epithelial cells and fibroblasts of adult rats by methylcholanthrene. Cancer Res. 33 : 2779-2785, 1973.

15) MacPherson, I. and Montagnier, L. : Agar suspension culture for the selective assay of cells transformed by polyoma virus. Virology 23 : 291-294, 1964.

16) Schneyer, C. A. and Schneyer, L. R.: Secretion by salivary glands deficient in acini. Am. J. Physiol. 201 : 939-944, 1961.

17) Newbrun, E. : Observations on the amylase content and flow rate of human saliva following gustatory stimulation. J. Dent. Res. 41: 459-465, 1962.

18) Jacobsen, N.: Salivary amylase. II. Alphaamylase in salivary glands of the Macaca irus monkey, the Cercopithecus aethiops monkey, and man. Caries Res. 4 : 200-205, 1970.

19) Radden, H. G.: Mouth wounds. Brit. Dent. J. 113 : 112-119, 1962.

20) Coleman, S. E. Rijn, I. V. and Bleiweis, A. S.: Lysis of cariogenic and non-cariogenic oral streptococci with lysozyme. J. Dent. Res. 50 : 939-943, 1971.

21) Helderman, W. H. : Lysozyme concentra- tions in the gingival crevice and at other oral sites in human subjects with and wihout gingivitis. Arch. Oral Biol. 21 : 251-255, 1976.

22) Dogon, I. L. and Amdur, B. H. : Evidence of the presence of two thiocyanate dependent antibacterial systems in human saliva. Arch. Oral Biol. 15 : 987-992, 1970.

23) Shillitoe, E. J. and Lehner, T. : Immunoglobulins and complement in crevicular fluid, serum and saliva in man. Arch. Oral Biol. $17: 241-247,1972$.

24) Wright, W. E. and Tempel, T. R. : Effect of oral hygiene on the clearance of soluble chemotactic bacterial products from human saliva. J. Periodent. 45 : 134-138, 1974.

25) Hammond, C. W. and Weinman, J. P. : Opsonin in saliva. J. Dent. Res. $21: 279-$ 283, 1942.

26) Levi-Montalcini, R. and Angeletti, P. V. : Nerve growth factor. Physiol. Rev. 48 : 534, 1968.

27) Gregory, H. : Isolation and structure of urogastrone and its relationship to epidermal growth factor. Nature 257 : 325-327, 1975.

28) Burgess, A. W., Camakaris, J. and Metcalf, D. : Purification and properties of colony stimulating factor from mouse lung-conditioned medium. J. Biol. Chem. 252 : 19982002, 1977.

29) MoLan, P. C. and Hartles, R. L.: The nature of the intrinsic salivary substrates used by the human oral flora. Arch. Oral Biol. 16 : 1449-1462, 1971.

30) MoLan, P. C. and Hartles, R. L. : A study of the enhancement of glycolysis in human saliva. Arch. oral Biol. 17 : 1671-1678, 1972. 